\title{
Diagnosis of Leptospira spp. Infection in Sheep Flocks in the State of Mato Grosso, Brazil
}

\author{
Camila Eckstein ', Luciano Bastos Lopes², Valéria Spyridion Moustacas ${ }^{3}$, \\ Rogério Oliveira Rodrigues ${ }^{4}$, Bruno Gomes de Castro' \& Renato Lima Santos ${ }^{3}$
}

\begin{abstract}
Background: Leptospirosis has a worldwide distribution with high social and economic impact. It is caused by a variety of Leptospira spp. serovars, particularly in tropical regions. Various species of animals can be affected by Leptospira spp. including cattle, horses, sheep, goats and swine, and can act as a reservoir for human infection. In Brazil, sheep leptospirosis has been diagnosed in a variety of States, however, little is known about sheep flocks of Mato Grosso. Considering the marked growth of sheep industry in Mato Grosso State in past recent years, this study aimed to evaluate the frequency of serologically positive sheep for Leptospira spp. serovars in the State of Mato Grosso (Brazil).

Materials, Methods \& Results: Blood samples of 346 sheep, which belonged to 16 sheep flocks of the medium northern region of Mato Grosso was obtained by jugular vein puncture. Serum was obtained by blood centrifugation and stored at $-20^{\circ} \mathrm{C}$ until the test to be performed. The diagnosis was performed using the microscopic agglutination test. Serovars Australis, Autumnalis, Bataviae, Bolívia, Castelonis, Celledoni, Grippotyphosa, Hardjo, Hardjobovis, Hebdomadis, Icterohaemorrhagiae, Javanica, Lagoa, Norma, Panama, Pomona, Sejroe, Shermani, Szwajizak, and Wolffi were tested. Reactions were considered positive with minimum titration of 1:100. Considering all serovars, $54.9 \%$ of sheep were positive, and the serovar more frequently detected was Celledoni (22.8\%), followed by Javanica (19.4\%), Castellonis (16.5\%), and Norma $(15.3 \%)$, with predominance of titration of 100 for these serovars, while only one sheep had a titration of 1:800 detected for serovar Hardjo. All flocks (100\%) were positive (at least one positive animal), with the frequency of animals positive to Leptospira spp. varying of $31.3 \%$ to $79.2 \%$ in flocks.

Discussion: Infection for Leptospira spp. in humans has a large social and sanitary impact. Under an animal health perspective, beyond sanitary impact, leptospirosis have a large economic impact and can act as important reservoirs for Leptospira spp. for human infection, especially in tropical conditions, which favor the persistence of agent in the environment. The occurrence of sheep leptospirosis has been diagnosed in several States of Brazil as Rio Grande do Sul, Paraíba, Rio de Janeiro, São Paulo and Maranhão, with frequency of herds positive for Leptospira spp. varying of 5.4\% to 47.4\%, however, the frequency of positive sheep in this study was higher than these previous reports in other Brazilian States. The most frequent serovar in sheep flocks have a great importance for prophylactic control. However, there were identified as main frequent serovar Celledoni and Javanica, which are considered unusual in sheep, and indicates a peculiar profile of ovine serovars for the region. Considering de high frequency of positive farms (100\%) in Mato Grosso and the lack of studies about the occurrence of leptospirosis in this region, our results suggest the occurrence of risk factors that can favor the dispersion and survival of agent. Contact of the sheep evaluated in this study with other animal species such as cattle, dogs, and horses that can serve as a source for sheep infection or may become contaminated from sheep. Then, the profile of sheep infection by Leptospira spp. in the State of Mato Grosso has a peculiar profile of serovars, with high frequency of infection of animals and herds.
\end{abstract}

Keywords: small ruminants, leptospirosis, serology. 


\section{INTRODUCTION}

Leptospirosis is an emerging infectious disease caused by several serovars of Leptospira. The disease has public health importance due to high incidence and severity of clinical manifestations in humans, in addition to the high economic impact for different animal species including cattle, horses, sheep, goats and swine [10].

Leptospira spp. survival for extended periods in environments with high temperature and humidity contribute for disease dispersion, especially in tropical regions [8]. In addition to these environmental conditions, the high population density and suitable reservoirs are determinant factors for disease occurrence and maintenance of the bacteria in the environment [11].

Thus, the broad climatic and environmental variations in Brazil are factors that contribute for a wide dispersion of infectious agents in different regions. This fact reflect in high variations of prevalence ( 5 to $47 \%$ ), according the studies performed in the States of Paraíba, São Paulo, Maranhão, Rio Grande do Sul, and Rio de Janeiro [1-3,5,9].

The sheep industry in the State of Mato Grosso has experienced marked growth over the past recent years [4]. According the last official data, the sheep population in Mato Grosso is 307,948 animals [7], representing $1.7 \%$ of national population. Importantly, dispersion of infectious agents and disease of sheep has been poorly studied in this region. The present work aimed to evaluate the frequency of serovars of Leptospira spp. in sheep flocks in the State of Mato Grosso.

\section{MATERIALS AND METHODS}

\section{Sampling}

By random sampling, 16 sheep flocks of the medium northern region of Mato Grosso were selected, including the municipalities of Sinop, Vera, Santa Carmen, and Ipiranga do Norte. One-year-old or older rams and ewes were sampled, resulting in 346 samples.

Blood collection and serology

Sampling was performed by external jugular vein puncture using vacuum tubes without anticoagulant. Blood samples were centrifuged, and sera were stored in triplicates at $-20^{\circ} \mathrm{C}$ until further testing.

Serologic diagnosis was performed by using the microscopic agglutination test (MAT), which was performed at the Instituto Desidério Finamor (Porto Alegre, Brazil). Samples that resulted in a minimum of
$50 \%$ of agglutinated Leptospira by microscopic field, with a minimum titration of $1: 100$, were considered positive. When positive on minimum titration, samples were sequentially diluted (1:200, 1:400, and 1:800). Antigens of serovars Australis, Autumnalis, Bataviae, Bolívia, Castelonis, Celledoni, Grippotyphosa, Hardjo, Hardjobovis, Hebdomadis, Icterohaemorrhagiae, Javanica, Lagoa, Norma, Panama, Pomona, Sejroe, Shermani, Szwajizak, and Wolffi were used.

\section{RESULTS}

All tested flocks were positive for at least one serovar $(100 \%)$ and the frequency of positive sheep per flock varied from $31.3 \%$ (5/16) to $76.5 \%$ (13/17), as detailed on Table 1.

In total, $54.9 \%$ of sheep were positive with minimal titration. The serovar more frequently detected was Celledoni (22.8\%), followed by Javanica (19.4\%), Castellonis (16.5\%) and Norma (15.3\%), with predominance of titration of 100 for these serovars, while only one sheep had a titration of 1:800 detected for serovar Hardjo. The serovar Autumnalis, Batavie, Shermani, and Szwajizak were not detected in any of the evaluated sheep (Table 2).

\section{DISCUSSION}

Leptospirosis results in large social and economic impact, especially in tropical conditions that favor the persistence of agent in the environment, and consequently transmission of disease [11]. Considering the high epidemiologic importance of reservoirs, the diagnosis of leptospirosis in sheep has been largely neglected. A high frequency of positive farms (100\%) and individual sheep $(54.9 \%)$ was observed in this study, which is the first seroepidemiological study of exposure to Leptospira spp. in sheep in the state of Mato Grosso, which supports the hypothesis that sheep may serve as an important reservoir of the agent.

The microscopic agglutination test (MAT) is the most largely used method of diagnosis for screening of leptospirosis. Sheep flocks of different Brazilian regions were evaluated by this technique, resulting in frequencies of $34.2 \%$ in Rio Grande do Sul [5], 5.4\% in Paraíba [1], 47.4\% in Rio de Janeiro [9], 23.0\% in São Paulo [2] and 32.0\% in Maranhão [3]. In spite of the broad variation in prevalences observed among different States, the frequency of positive sheep in this study was higher than these previous reports in other Brazilian states. 
C. Eckstein, L.B. Lopes, V.S. Moustacas, et al. 2017. Diagnosis of Leptospira spp. Infection in Sheep Flocks in the State of Mato Grosso, Brazil.

Table 1. Detailed information by flock diagnosed with Leptospira spp. on medium northern region of Mato Grosso State, Brazil.

\begin{tabular}{|c|c|c|c|c|c|c|}
\hline Flock & City & $\begin{array}{l}\text { Total of } \\
\text { sheep } \\
\text { per } \\
\text { flock }\end{array}$ & $\begin{array}{l}\text { Evaluated } \\
\text { animals }\end{array}$ & $\begin{array}{l}\text { Animal } \\
\text { species } \\
\text { with direct } \\
\text { contact }\end{array}$ & $\begin{array}{l}\text { Frequency } \\
\text { of positive } \\
\text { sheep }\end{array}$ & Positive serovars \\
\hline 1 & Sinop & 62 & $\begin{array}{c}17 \\
(27.4 \%)\end{array}$ & Cattle & $76.5 \%$ & $\begin{array}{c}\text { Bolívia, Castellonis, Celledoni, Hardjobovis, Javanica, } \\
\text { Lagoa, Norma, Panamá, Pomona and Wolffi }\end{array}$ \\
\hline 2 & Sinop & 100 & $\begin{array}{c}26 \\
(26.0 \%)\end{array}$ & - & $73.1 \%$ & $\begin{array}{c}\text { Bolívia, Castelonis, Celledoni, Grippotyphosa, Hardjo, } \\
\text { Hardjobovis, Hebdomadis, Javanica, Lagoa, Norma and } \\
\text { Wolffi }\end{array}$ \\
\hline 3 & Sinop & 50 & $\begin{array}{c}12 \\
(24.0 \%)\end{array}$ & - & $41.7 \%$ & $\begin{array}{l}\text { Bolívia, Castelonis, Celledoni, Hebdomadis, Javanica, } \\
\text { Lagoa, Norma, Panama, Pomona }\end{array}$ \\
\hline 4 & $\begin{array}{c}\text { Santa } \\
\text { Carmem }\end{array}$ & 50 & $\begin{array}{c}18 \\
(36.0 \%)\end{array}$ & $\begin{array}{l}\text { cattle, dogs, } \\
\text { and horses }\end{array}$ & $44.4 \%$ & $\begin{array}{l}\text { Bolívia, Castelonis, Celledoni, Hebdomadis, Javanica, } \\
\text { Norma, Panama }\end{array}$ \\
\hline 5 & Sinop & 200 & $\begin{array}{c}29 \\
(14.5 \%)\end{array}$ & $\begin{array}{l}\text { cattle, dogs, } \\
\text { and horses }\end{array}$ & $58.6 \%$ & $\begin{array}{c}\text { Bolívia, Castelonis, Celledoni, Grippotyphosa, } \\
\text { Hebdomadis, Javanica, Lagoa, Norma, Panama, } \\
\text { Pomona and Wolffi }\end{array}$ \\
\hline 6 & Sinop & 50 & $\begin{array}{c}24 \\
(48.0 \%)\end{array}$ & Cattle & $79.2 \%$ & $\begin{array}{c}\text { Australis, Bolívia, Castelonis, Celledoni, } \\
\text { Grippotyphosa, Hebdomadis, Javanica, Lagoa, Norma, } \\
\text { Panama, Pomona andWolffi }\end{array}$ \\
\hline 7 & $\begin{array}{c}\text { Santa } \\
\text { Carmem }\end{array}$ & 250 & $18(7.2 \%)$ & - & $61.1 \%$ & $\begin{array}{c}\text { Bolívia, Castelonis, Celledoni, Grippotyphosa,Javanica, } \\
\text { Norma, Panama, Pomona and Wolffi }\end{array}$ \\
\hline 8 & Sinop & 800 & $34(4.2 \%)$ & - & $32.4 \%$ & $\begin{array}{l}\text { Bolívia, Castelonis, Celledoni, Hebdomadis, Javanica, } \\
\text { Lagoa, Pomona and Wolffi }\end{array}$ \\
\hline 9 & Vera & 5.000 & $82(1.6 \%)$ & Dogs & $48.8 \%$ & $\begin{array}{c}\text { Australis,Bolívia, Castelonis, Celledoni, } \\
\text { Grippotyphosa, Hardjo, Hardjobovis, Hebdomadis, } \\
\text { Icterohaemorrhagiae, Javanica, Lagoa, Norma, Panama, } \\
\text { Pomona e Wolffi }\end{array}$ \\
\hline 10 & $\begin{array}{l}\text { Ipiranga } \\
\text { do Norte }\end{array}$ & 54 & $\begin{array}{c}16 \\
(29.6 \%)\end{array}$ & - & $31.3 \%$ & $\begin{array}{l}\text { Castelonis, Celledoni, Hardjobovis, Javanica, Norma, } \\
\text { Panama and Wolffi }\end{array}$ \\
\hline 11 & $\begin{array}{l}\text { Ipiranga } \\
\text { do Norte }\end{array}$ & 101 & $\begin{array}{c}23 \\
(22.8 \%)\end{array}$ & Cattle & $65.2 \%$ & $\begin{array}{l}\text { Castelonis, Celledoni, Hardjo, Hardjobovis, Javanica, } \\
\text { Norma, Panama, Pomona, Sejroe and Wolffi }\end{array}$ \\
\hline 12 & $\begin{array}{l}\text { Ipiranga } \\
\text { do Norte }\end{array}$ & 15 & $8(53.3 \%)$ & $\begin{array}{l}\text { cattle, dogs, } \\
\text { and horses }\end{array}$ & $50.0 \%$ & Bolívia, Castelonis, Celledoni, Panama and Wolffi \\
\hline 13 & $\begin{array}{l}\text { Ipiranga } \\
\text { do Norte }\end{array}$ & 12 & $9(75.0 \%)$ & Cattle & $66.7 \%$ & Castelonis, Celledoni, Hardjobovis and Javanica \\
\hline 14 & Sinop & 18 & $\begin{array}{c}12 \\
(66.7 \%)\end{array}$ & $\begin{array}{l}\text { cattle, dogs, } \\
\text { and horses }\end{array}$ & $50.0 \%$ & Castelonis, Celledoni and Javanica \\
\hline 15 & Sinop & 9 & $\begin{array}{c}9 \\
(100.0 \%)\end{array}$ & $\begin{array}{l}\text { cattle, dogs, } \\
\text { and horses }\end{array}$ & $55.6 \%$ & Castelonis, Celledoni, Javanica, Norma andPanama \\
\hline 16 & Sinop & 19 & $9(47.4 \%)$ & Dogs & $66.7 \%$ & Castelonis, Celledoni, Javanica and Norma \\
\hline
\end{tabular}


Table 2. Frequency of sheep serologically positive for Leptospira spp. serovars and maximum titration detected by microscopic agglutination test on medium northern region of Mato Grosso State, Brazil.

\begin{tabular}{|c|c|c|c|c|c|c|}
\hline \multirow{2}{*}{ Serovar } & \multirow{2}{*}{$\begin{array}{l}\text { Relative } \\
\text { frequency }\end{array}$} & \multirow{2}{*}{$\begin{array}{l}\text { Absolut } \\
\text { frequency }\end{array}$} & \multicolumn{4}{|c|}{ Titration } \\
\hline & & & 100 & 200 & 400 & 800 \\
\hline Australis & $0.6 \%$ & $2 / 346$ & 1 & 1 & 0 & 0 \\
\hline Autumnalis & $0.0 \%$ & $0 / 346$ & 0 & 0 & 0 & 0 \\
\hline Bataviae & $0.0 \%$ & $0 / 346$ & 0 & 0 & 0 & 0 \\
\hline Bolívia & $7.2 \%$ & $25 / 346$ & 20 & 4 & 1 & 0 \\
\hline Castelonis & $16.5 \%$ & $57 / 346$ & 51 & 6 & 0 & 0 \\
\hline Celledoni & $22.8 \%$ & $79 / 346$ & 61 & 18 & 0 & 0 \\
\hline Grippotyphosa & $1.4 \%$ & $5 / 346$ & 4 & 1 & 0 & 0 \\
\hline Hardjo & $2.3 \%$ & $8 / 346$ & 7 & 0 & 0 & 1 \\
\hline Hardjobovis & $5.5 \%$ & $19 / 346$ & 17 & 2 & 0 & 0 \\
\hline Hebdomadis & $3.8 \%$ & $13 / 346$ & 11 & 2 & 0 & 0 \\
\hline Icterohaemorrhagiae & $0.3 \%$ & $1 / 346$ & 1 & 0 & 0 & 0 \\
\hline Javanica & $19.4 \%$ & $67 / 346$ & 66 & 1 & 0 & 0 \\
\hline Lagoa & $4.3 \%$ & $15 / 346$ & 12 & 3 & 0 & 0 \\
\hline Norma & $15.3 \%$ & $53 / 346$ & 48 & 4 & 1 & 0 \\
\hline Panama & $4.0 \%$ & $14 / 346$ & 13 & 1 & 0 & 0 \\
\hline Pomona & $4.3 \%$ & $15 / 346$ & 13 & 2 & 0 & 0 \\
\hline Sejroe & $0.3 \%$ & $1 / 346$ & 1 & 0 & 0 & 0 \\
\hline Shermani & $0.0 \%$ & $0 / 346$ & 0 & 0 & 0 & 0 \\
\hline Szwajizak & $0.0 \%$ & $0 / 346$ & 0 & 0 & 0 & 0 \\
\hline Wolffi & $5.5 \%$ & $19 / 346$ & 18 & 1 & 0 & 0 \\
\hline
\end{tabular}

Moreover, the high frequency of positive farms $(100 \%)$ in Mato Grosso suggests the occurrence of risk factors that can favor the dispersion and survival of agent. In this context, the elevated rainfall in concentrated periods of the year in this region may favor the persistence of the agent, favoring infection [11].

Different serovars were more prevalent in different regions of Brazil. For instance, sorovar Autumnalis was the most frequent in the State of São Paulo [2], serovar Grippotyphosa in Maranhão [3], and serovar Hardjo in Rio Grande do Sul [5]. In this study, serovars Celledoni and Javanica were the most frequent, whereas these serovars have been rarely found previously in sheep [6]. The Javanica serovar in sheep is commonly associated with sharing pastures and premises with cattle [2]. Identification of uncommon serovars indicates a peculiar profile of ovine serovars for the region, emphasizing the importance of the studies to determine the need for serovar-specific vaccination.

\section{CONCLUSION}

In conclusion, our results indicated $54.9 \%$ of positive individual sheep and $100 \%$ of positive sheep farms by the microscopic agglutination test (MAT), which was the first seroepidemiological study of leptospirosis in sheep in the State of Mato Grosso, Brazil.

Funding. Financial assistance for this research was provided by FAPEMAT to VSM. The work in RLS laboratory is supported by CNPq, FAPEMIG and CAPES.

Ethical approval. All animal protocols have been reviewed and approved by the Ethics Committee on the Use of Animals of Embrapa Agrossilvipastoril (Animal use permit: Protocol 004/2015).

Declaration of interest. The authors report no conflicts of interest. The authors alone are responsible for the content and writing of the paper. 


\section{REFERENCES}

1 Alves C.J., Alcindo J.F., Farias A.E., Higino S.S.S., Santos F.A., Azevedo S.S., Costa D.F. \& Santos C.S.A.B. 2012. Caracterização epidemiológica e fatores de risco associados à leptospirose em ovinos deslanados do semiárido brasileiro. Pesquisa Veterinária Brasileira. 32(6): 523-528.

2 Barbante P., Shimabukuro F.H., Langoni H., Richini-Pereira V.B. \& Lucheis S.B. 2014. Leptospira spp. infection in sheep herds in southeast Brazil. Journal of Venomous Animals and Toxins including Tropical Diseases. 20(1): 20.

3 Carvalho S.M., Mineiro A.L., Castro V., Genovez M.E., Azevedo S.S. \& Costa F.A.L. 2014. Leptospirosis seroprevalence and risk factors for sheep in Maranhão State, Brazil. Tropical Animal Health and Production. 46(2): 491-494.

4 Hermuche P.M., Maranhão R.L.A., Guimarães R.F., Carvalho Júnior O.A., Gomes R.A.T., Paiva S.R. \& McManus C. 2013. Dynamics of sheep production in Brazil. ISPRS International Journal of Geo-Information. 2(3): 665-679.

5 Herrmann G.P., Lage A.P., Moreira E.C., Haddad J.P.A., Resende J.R., Rodrigues R.O. \& Leite R.C. 2004. Soroprevalência de aglutininas anti-Leptospira spp. em ovinos nas Mesorregiões Sudeste e Sudoeste do Estado Rio Grande do Sul, Brasil. Ciência Rural. 34(2): 443-448.

6 Higino S.S.S. \& Azevedo S.S. 2014. Leptospirose em pequenos ruminantes: situação epidemiológica atual no Brasil. Arquivos do Instituto Biológico. 81(1): 86-94.

7 Instituto Brasileiro de Geografia e Estatística (IBGE). 2013. Pesquisa pecuária Municipal. Available at $<$ http://www. sidra.ibge.gov.br/bda/tabela/protabl.asp?c=3939\&z=p\&o=28\&i=P>. [Accessed online in August 2016].

8 Levett P.N. 2001. Leptospirosis. Clinical Microbiology Reviews. 14(2): 296-326.

9 Martins G., Penna B., Hamond C., Leite R.C., Silva A., Ferreira A., Brandão F., Oliveira F. \& Lilembaum W. 2012. Leptospirosis as the most frequent infectious disease impairing productivity in small ruminants in Rio de Janeiro, Brazil. Tropical Animal Health and Production. 44(4): 773-777.

10 Martins G. \& Lilenbaum W. 2013. The panorama of animal leptospirosis in Rio de Janeiro, Brazil, regarding the seroepidemiology of the infection in tropical regions. BMC Veterinary Research. 9(1): 237.

11 Petrakovsky J., Bianchi A., Fisun H., Nájera-Aguilar P. \& Pereira M.M. 2014. Animal Leptospirosis in Latin America and the Caribbean countries: Reported outbreaks and literature review (2002-2014). International Journal of Environmental Research and Public Health. 11(10): 10770-10789. 